\title{
LA CASA DE LOS MIRADORES DE DIEGO DE SILOE: UN PALCO EN LA PLAZA MAYOR DE GRANADA
}

\author{
JuAn MANUEl BarRios RozÚA ${ }^{1}$ \\ Universidad de Granada
}

\begin{abstract}
Por orden del cabildo municipal de Granada el arquitecto Diego de Siloe diseñó para la plaza de Bibarrambla un edificio de miradores que constituyó uno de los más armoniosos ejemplos en su género. El artículo intenta completar nuestra visión de este notable ejemplo de la arquitectura civil del renacimiento español aportando algunas precisiones descriptivas, el análisis de sus orígenes compositivos, y la historia de las transformaciones y usos que conoció.
\end{abstract}

Palabras clave: Arquitectura; Renacimiento; plaza mayor; arquitectura efímera.

\section{THE HOUSE OF THE MIRADORES BY DIEGO DE SILOE:}

A VIEWING BOX ON THE MAIN SQUARE OF GRANADA

By order of the local council of Granada, the arquitect Diego de Siloe designed the house of the Miradores on Bibarrambla square, one of the most harmonious examples of its kind. This article tries to complete our vision of this remarkable example of Spanish Renaissance civil architecture by providing descriptive details, unpublished images, the analysis of its compositional origins and the history of its transformations and uses.

Key words: Architecture; Spanish Renaissance; main square; ephemeral architecture.

Como citar este artículo/Citation: Barrios Rozúa, Juan Manuel (2017): "La casa de los Miradores de Diego de Siloe: un palco en la plaza mayor de Granada". En: Archivo Español de Arte, vol. 90, núm. 357, Madrid, pp. 1-18; doi: 10.3989/aearte.2017.01.

\section{La casa de los Miradores: el palco de las autoridades civiles}

\section{Una tribuna en la plaza mayor}

En tiempos nazaríes la plaza de Bibarrambla era una explanada rectangular de pequeñas dimensiones limitada a occidente por la muralla nazarí y a oriente por la Alcaicería. Nada sabemos de la fisonomía que pudieron tener los edificios que rodeaban esta explanada. Los Reyes Católicos cedieron el espacio al municipio en 1509 y determinaron que fuera destinado a lugar de esparcimiento y negocios. La plaza resultó pequeña desde el principio para lo concurrida que era, así en 1512 se decidió construir una plaza más grande que la explanada musulmana ${ }^{2}$. Una década después había una plaza mayor que presentaba rasgos coherentes en la mayoría de los edificios, aunque quedara lejos de una composición geométrica; una plaza que siguiendo a Luis Cervera Vera cabría clasificar de ordenada, término intermedio con el que describía las plazas

\footnotetext{
1 jmb@ugr.es / ORCID iD: http://orcid.org/0000-0002-5383-8873

2 Acale, 2005: 67-76 y 265.
} 


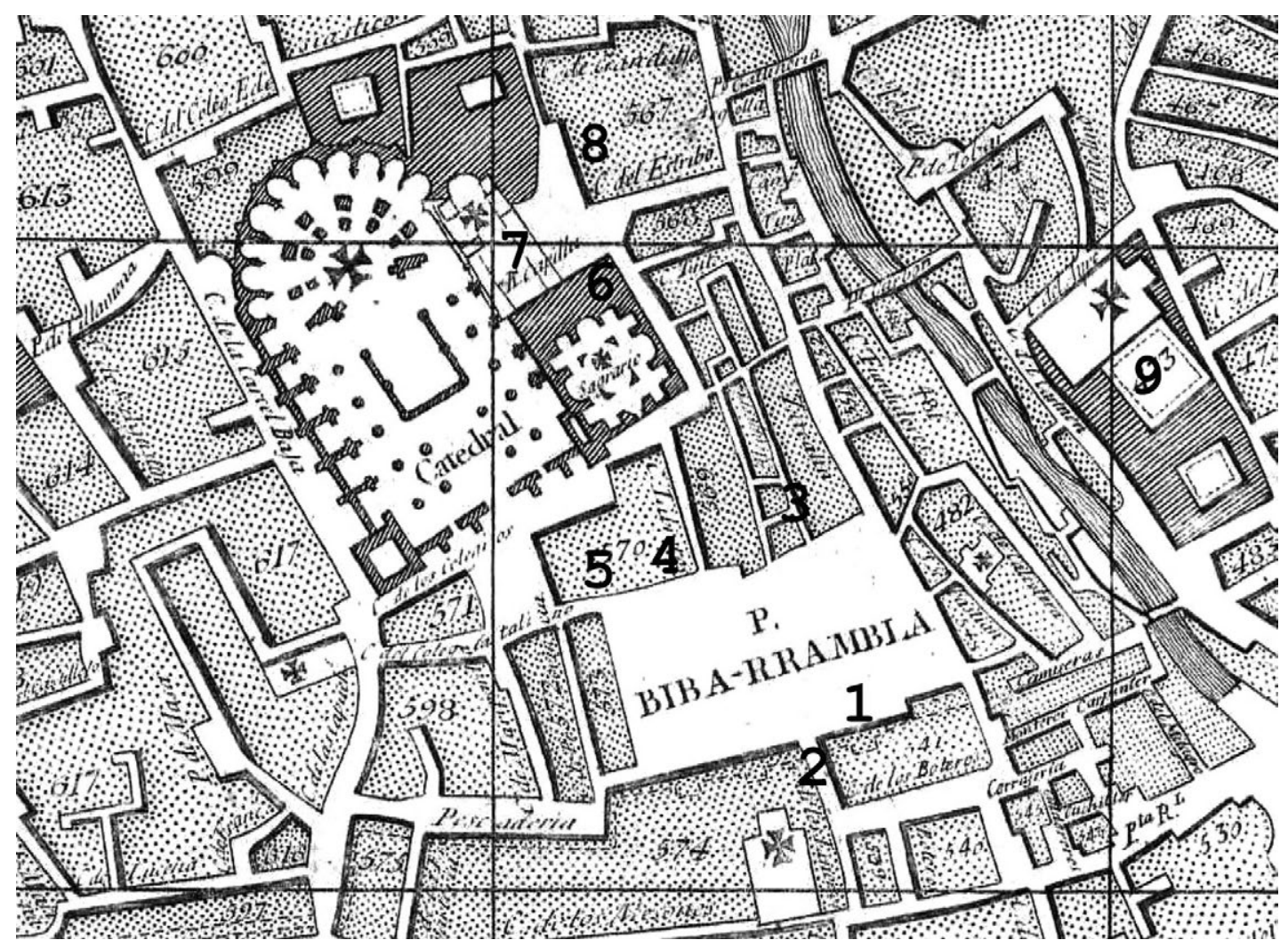

Fig. 1. Plano con los edificios citados: 1. Casa de los Miradores; 2. Arco de las Cucharas; 3. Alcaicería; 4. Palacio Arzobispal; 5. Colegio Real; 6. Lonja; 7. Capilla Real; 8. Madraza (cabildo municipal); 9. Convento del Carmen, desde 1851 sede del Ayuntamiento.

que no eran improvisadas, típicas de tantos pueblos, ni programadas, como las grandes plazas que en fechas posteriores a la de Granada se edificaron en Valladolid y Madrid ${ }^{3}$. Es posible que hubiera unas directrices municipales para que los distintos promotores construyeran sus casas, pues todas tenían el mismo diseño modular, aunque variaban en número de plantas o anchura. Los inmuebles eran de una notable altura, pues con sus entre cuatro y seis cuerpos de alzada eran los edificios de viviendas más elevados de la ciudad y los únicos cuyas fachadas no eran muros maestros sino estructuras de pilares que permitían amplias galerías y balcones; los pilares y muretes de ladrillo estaban enlucidos en blanco y pronunciados aleros protegían las fachadas. De estas posibles directrices, de las que no conservamos documentación, quedarían exceptuados el Colegio Real, el palacio Arzobispal y la casa de los Miradores, levantados con posterioridad (fig. 1). Los propietarios de los edificios de fábrica mudéjar fueron durante el Antiguo Régimen nobles e instituciones religiosas (Inquisición, monasterio de la Cartuja, etc.). Las viviendas que se podían habilitar en las habitaciones que había tras las galerías eran angostas y en el siglo XVIII las encontramos arrendadas a personas del pueblo $11 \mathrm{lano}^{4}$. Es evidente que los propietarios, miembros de la nobleza y el clero, sólo hacían uso de los miradores cuando se celebraban eventos en la plaza.

\footnotetext{
3 Cervera, 1990: 40-41.

${ }^{4}$ Los informes de obras en la plaza realizados en el siglo XVIII nos dan interesantes datos sobre los propietarios e inquilinos; también sobre los materiales constructivos de los edificios (Archivo Histórico Municipal de Granada, en adelante AHMG, leg. 35-31, 907-15 y 907-23).
} 
Los nobles que componían el cabildo municipal, conocidos como caballeros veinticuatro, deseaban una tribuna o palco privilegiado para ese "gran teatro urbano", en palabras de Rafael López Guzmán, que era la plaza mayor; para este fin mandaron construir un edificio "incomprensible si aislamos su funcionamiento del recinto que lo acoge" ${ }^{5}$. Cuando en 1599 Diego de Cuelvis visitó la ciudad escribió: "En esta plaça ay una casa grande y casi Audiencia de la Ciudad, donde estan los Señores grandes de Granada quando se hazen fiestas en sacando los Toros o Juegos de Cañas"6. Este edificio, a lo largo de su dilatada historia sería conocido con distintas variantes de su nombre: Miradores, Mirador o Casa de los Miradores, y en ocasiones también como el edificio del Cabildo en la plaza de Bibarrambla.

\section{Proceso constructivo y descripción}

Los Reyes Católicos cedieron al Ayuntamiento en el año 1500 una casa de la plaza de Bibarrambla para que sirviera de miradores de las autoridades municipales en los espectáculos que en ella se celebraran ${ }^{7}$. No sabemos si era una casa musulmana remodelada o si se reconstruyó, pero en cualquier caso cabe suponerla de modesta factura. Décadas después el cabildo municipal de Granada encargó a Diego de Siloe que trazara unos miradores en ese solar, comenzando las obras en $1556^{8}$. Cuatro años después sólo se había realizado la arcada del primer cuerpo y quizás surgió algún tipo de problema con los pagos, porque el 20 de septiembre de 1560 se aprobaron unas "Condiciones" para la obra escritas por Diego de Siloe que incluían con precisión todas las medidas, materiales y detalles constructivos, intentando aclarar los detalles de un diseño en pergamino que sin lugar a dudas había realizado años antes y era el seguido en la primera etapa de los trabajos. En estas "Condiciones", publicadas por Manuel Gómez-Moreno Martínez, queda claro que el anciano Diego de Siloe no labrará los escudos y que serán los munícipes quienes elijan al escultor. Además, el propio Siloe reconoce que la traza en pergamino es demasiado pequeña e imprecisa para que la persona que talle los elementos constructivos pueda sacar de ella las proporciones correctas, de ahí que este maestro deberá tener cuidado de que "este edefiçio no carezca de las medidas que los famosos arquitectos romanos e griegos constituyeron" y que además "tenga entendido el dicho maestro que este edefiçio a de azer ventaja a todo lo que asta agora se a labrado en otras cosas que la dicha çibdad a mandado e dado a labrar" . O sea, que la casa de los Miradores debía ser la fachada de más perfectas proporciones clásicas de una ciudad en la que no se había afrontado nunca un reto de tales características, salvo el inconcluso palacio de Carlos V en la ciudadela de la Alhambra.

La casa de los Miradores fue el último proyecto de un Diego de Siloe ya anciano, el cual falleció cuando las obras estaban sólo empezadas. La ejecución del diseño estuvo a cargo del cantero Pedro de Astiazu ${ }^{10}$, discípulo del arquitecto burgalés que había trabajado bajo su dirección en las obras de la Catedral, mientras que Juan de Maeda realizó tareas de reconocimien-

\footnotetext{
5 López, 1987: 519-520.

${ }^{6}$ Diego de Cuelvis cita una inscripción en la fachada que decía: "GRANADA MANDO HAZER ESTA OBRA SIENDO EN ELLA CORREGIDOR EL MUY ILLUSTRE SEÑOR JUAN RODRIGUES DE LA UILLA EN EL AÑO M. D. LXIX" (Luque, 2013: 568).

${ }^{7}$ La cesión se hizo por real carta en Granada el 20 de septiembre de 1500, y fue confirmada el 15 de octubre de ese mismo año. Así lo afirma el Ayuntamiento en un informe fechado en 1856 y basado en un documento de su propio archivo (AHMG, leg. 3577-5).

${ }^{8}$ El primer libramiento de dinero para las obras está fechado el 18 de agosto de 1556 (López, 1987: 520). Fue Manuel Gómez-Moreno González quien señaló por primera vez que el autor era Diego de Siloe, y apuntó como la fecha del encargo el año 1540, aunque indica que las obras no empezarían hasta 1556 (Gómez-Moreno González, 1892: 246).

9 Las "Condiciones para la casa de los Miradores en Granada", con las medidas de los elementos, están publicadas como apéndice en Gómez-Moreno Martínez, 1983: 196-198.

10 Este cantero estaba activo desde 1540 y adquirió una buena posición económica, como lo demuestra que en 1566 vendiera "un esclavo negro llamado Cristóbal, de veintidós años" (Gómez-Moreno Calera, 1989: 40 y Gila, 2000: 88).
} 


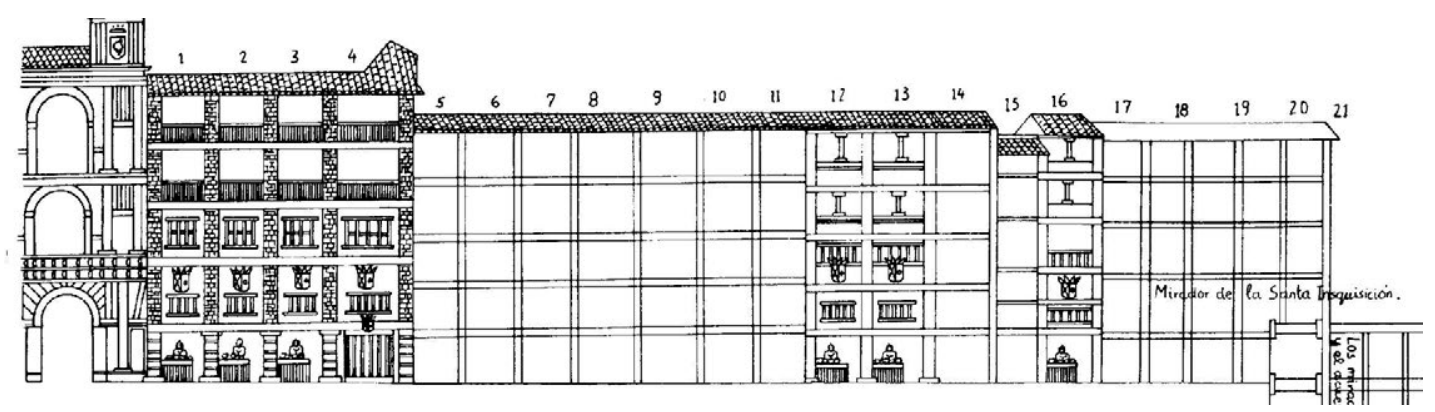

Fig. 2. Acera de los Miradores; el edificio del cabildo municipal se ve incompleto a la izquierda (1616, Archivo Histórico Nacional).

to ${ }^{11}$. Las obras se dieron por concluidas en 1583, fecha en la que se colocó en el anexo arco de las Cucharas una inscripción ${ }^{12}$. El balcón principal se añadió entre 1585 y 1587, siendo su traza de Leandro de Palencia y encargándose de fundirlo los rejeros Alonso López y Alonso Pérez, y de dorarlo el pintor y decorador Luis Carrillo ${ }^{13}$.

La fachada del edificio se componía de tres pisos separados por entablamentos completos y con cinco arcos simétricos en cada uno de ellos. La serie modular de arcos se cerraba en los extremos con unos machones con dobles columnas adosadas y un estrecho intercolumnio entre ellas. La fachada tenía una sobria bicromía por estar construida de piedra Santa Pudia, de color "blanco" según se especifica en el contrato, combinada con piedra de Elvira gris que se utilizará en las columnas y molduras. Era sobria en su ornamentación, sobre todo si se compara con las anteriores obras de Siloe, lo que demuestra su evolución hacia una estética basada en la geometría, el ritmo y los contrastes de luces y sombras (fig. 2).

El canon de las columnas era más esbelto que el utilizado en la Italia del pleno renacimiento. El cuerpo inferior tenía medias columnas toscanas ("áticas") sobre pedestales y unos arcos carentes de decoración; en las enjutas un sencillo adorno semiesférico. La galería del piso principal contaba con medias columnas jónicas sobre pedestales y arcos con una ménsula en la clave, y en la galería del tercer piso las medias columnas eran corintias. Inicialmente estuvo previsto que el edificio se coronara con una galería de diez arcos sobre pilares cuadrados, elemento que habría enriquecido la composición alejándola de su modelo, que como veremos más adelante es la Logia de la Bendición, pero la galería nunca se construyó (véase la fotocomposición que hago en la fig. 3). Se remataba la fachada con una balaustrada en cuyo centro estaba el escudo real con el águila, y las armas y divisas de Granada en los extremos; cada escudo estaba coronado por un original frontón configurado por dobles volutas inclinadas, entre ellas un medallón y sobre él una granada.

La galería baja del edificio daba continuidad a los soportales que rodeaban la plaza de Bibarrambla, con la peculiaridad de que el arco del extremo derecho comunicaba con la puerta de las Cucharas ${ }^{14}$. En el interior destacaba una escalera de cierta monumentalidad, decorada con el águila imperial y un escudo de armas, la cual se realizó en 1624 con motivo de la venida de

11 Juan de Maeda trabajó en otros edificios trazados por Siloe, como la iglesia parroquial de Iznalloz, cuya cabecera casi parece la fachada de un palacio (Gómez-Moreno Martínez, 1963: 46).

${ }^{12}$ La inscripción era la siguiente: "Granada mandó hacer esta obra siendo corregidor el muy ilustre Sr. Don Francisco de Carbajal Señor de la Villa de Torrejón el Rubio, año de 1583" (documento del año 1867 en el que se cita un documento municipal de 1610, AHMG, 18-175).

13 López, 1987: 522.

14 Esta puerta era un sencillo arco abierto en la muralla nazarí en 1519 para comunicar la plaza con la carnicería y el cada vez más populoso barrio de la Magdalena (Giménez-Serrano, 1846: 172 y Gómez-Moreno González, 1892: 247). 


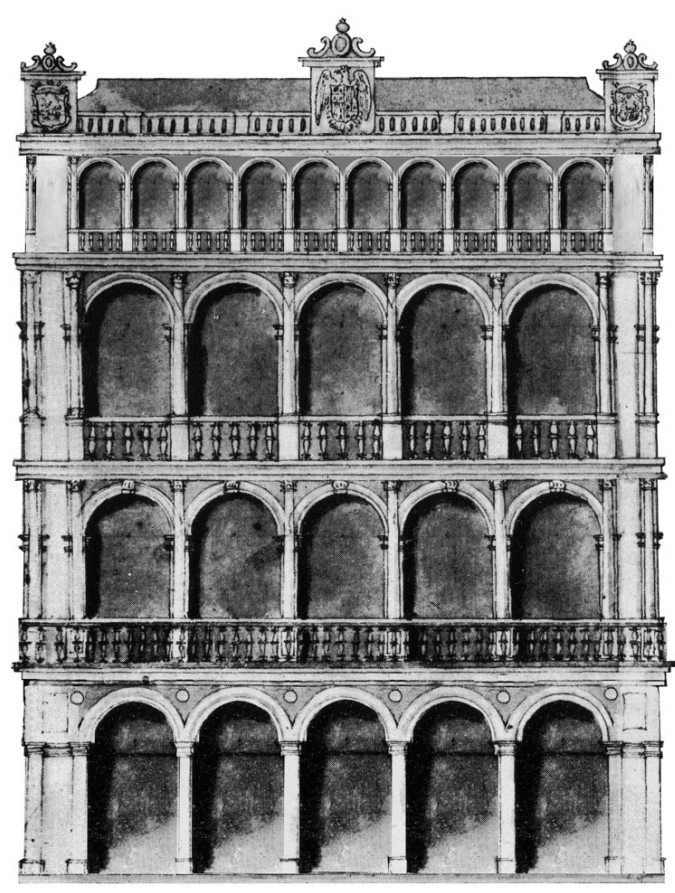

Fig. 3. Propuesta de restitución de la galería superior prevista en el diseño de Diego de Siloe (J. M. Barrios a partir de la fig. 6).

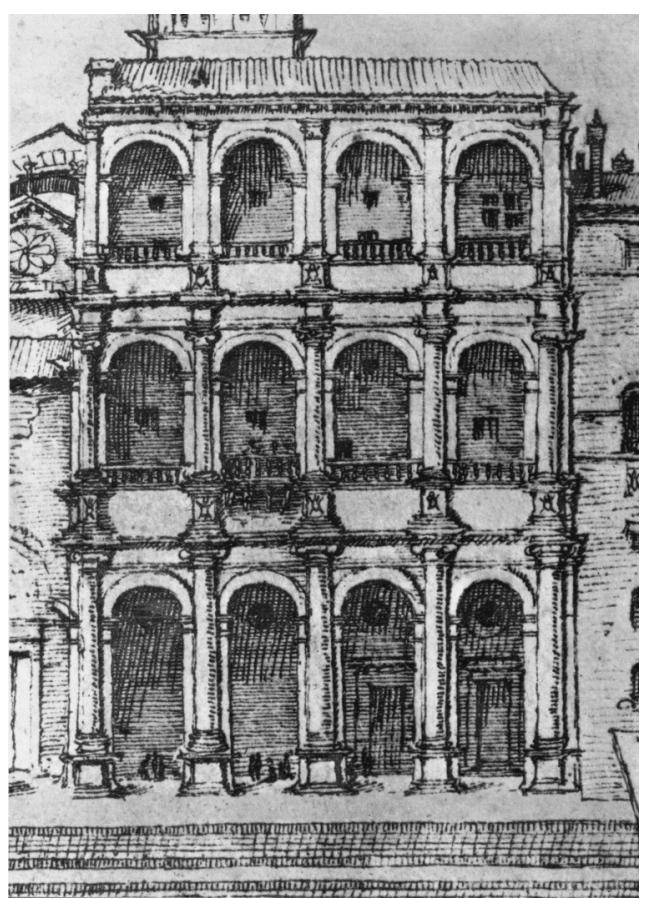

Fig. 4. Logia de la Bendición en Roma (dibujo de Pirro Ligorio).

Felipe IV ${ }^{15}$. En cuanto a las dependencias del edificio, destacaba un gran salón del piso principal, cubierto con un notable techo de artesones con friso ricamente tallado, y una sala de la planta superior que contaba con una armadura mudéjar ${ }^{16}$.

\section{Precedentes italianos}

Diego de Siloe trabajó en Nápoles en 1517 y 1518, y es probable que realizara alguna visita a Roma ${ }^{17}$. Además, desde que se estableció en Granada hubo de mantener relación con Pedro Machuca, un arquitecto que había residido en la ciudad eterna y se había formado en la estela de Bramante. En Roma estaban los precedentes compositivos de los Miradores, el primero de los cuales era el Tabularium (78 a. C.) en el cual el arquitecto Lucius Cornelius combinó una estructura de arcos de medio punto y bóvedas con una piel adintelada con órdenes clásicos, logrando una magistral fusión de la sólida construcción romana con la refinada gramática compositiva griega. El Tabularium estaba demasiado ruinoso y camuflado en el siglo XVI como para que ningún arquitecto viera en él nada digno de inspiración, pero había dos edificios posteriores que aplicaban la solución de manera magistral en fachadas curvas, el Teatro Marcello (11 a. C.) y el

15 AHMG, leg. 63.

${ }^{16}$ La descripción de los salones procede de Gómez-Moreno González, 1892: 247. Giménez Serrano destaca la "grandiosidad de su artesonado que es de madera y casetones labrados" (Giménez-Serrano, 1846: 173).

${ }_{17}$ Casi nada se sabe de la estancia en Nápoles de Siloe, salvo que trabajó en la capilla Caracciollo di Vico de la iglesia de San Giovanni a Carbonara junto al escultor Bartolomé Ordóñez (Gómez-Moreno Martínez, 1963: 16-17 y López, 1987: 31). 
prestigioso Coliseo (70-80 d. C.), el edificio que en realidad iba a convertirse en la fuente de inspiración de los arquitectos del renacimiento.

Leon Battista Alberti en el palacio Rucellai (Florencia, 1446-1455) se valió, para ordenar los tres cuerpos de alzada de la fachada, de una superposición de órdenes que claramente está inspirada en el Coliseo, pero no encontramos una estructura continua de arcos y bóvedas a la que se añada la piel adintelada, sino un macizo muro horadado por ventanas con parteluz, una solución más teatral que estructural ${ }^{18}$.

El más claro precedente de los Miradores es un edificio desaparecido, la Logia de la Bendición, que se asomaba a la gran plaza del Vaticano antes de que Bernini la remodelara (fig. 4). Su construcción se inició en 1461 reutilizando gigantescas columnas del pórtico de Octavio y dio como resultado, tras una larga y azarosa construcción, una imponente logia de tres cuerpos de alzada y cuatro tramos de arcos con piel adintelada y superposición jerárquica de órdenes. Este edificio lo trazó Francesco del Borgo, el único discípulo directo de Alberti y el primer arquitecto de la época en realizar una arquitectura con una estructura masiva al modo del Coliseo. La Logia de la Bendición, aun siendo la más directa fuente de inspiración de los Miradores, presenta diferencias que es preciso poner de relieve: tiene menos tramos de arcos, estos no están enmarcados por machones, el tercer cuerpo sustituye las medias columnas por pilastras planas y el edificio se remata con un sencillo tejado. El éxito de este diseño lo prueba que el propio Francesco del Borgo diseñara el inacabado patio principal del palacio Venezia y la fachada de la anexa iglesia de San Marcos (hacia 1460-1470) ${ }^{19}$.

La solución trascendió Roma y llegó a Venecia, donde el arquitecto Mauro Codussi diseñó el grandioso palacio Loredan-Vendramin (1502) utilizando la fórmula de la Logia de la Bendición, pero enriqueciéndola con una duplicación de las medias columnas en los pilares, salvo en los arcos centrales, y dividiendo las ventanas con parteluces, todo lo cual generaba un ritmo más complejo y una impresión de abigarrada riqueza ornamental tan acorde con el gusto veneciano. Esta fachada era todo un mirador al Gran Canal, escenario de vistosas procesiones de barcazas $^{20}$.

Variaciones del modelo del Coliseo encontramos en obras de Bramante que fueron más accesibles al conocimiento del arquitecto burgalés. Destaca el Cortile del Belvedere del Vaticano (desde 1510), cuyos largos corredores tenían sólo en el cuerpo inferior un diseño análogo al Coliseo, mientras que en el principal y el superior apostaban por composiciones de vanos adintelados. Estos corredores estaban concebidos como tribunas para alojar a los espectadores en las celebraciones que se desarrollaban en un patio cuyas dimensiones sólo tenían parangón con proyectos de la Roma imperial, en cuya arquitectura para espectáculos Bramante se inspiró ${ }^{21}$.

La influencia de estos precedentes italianos es patente en Diego de Siloe no sólo en los Miradores, sino en algunas obras que trazó con antelación, como la capilla mayor de la Catedral de Granada y sobre todo el colegio del Arzobispo (Salamanca, 1529-1534). Este patio tiene en su primer cuerpo columnas compuestas adosadas a pilares que soportan arcos de medio punto, composición que es un clarísimo y temprano precedente de los Miradores que trazará lustros después, aunque aquí prima la horizontalidad. El segundo cuerpo, sin embargo, difiere al utilizar columnas abalaustradas adosadas a unos pilares que soportan arcos carpaneles ${ }^{22}$.

${ }_{18}$ El palacio Rucellai como precedente de los Miradores de Granada fue señalado por Marías, 1989: 426.

19 Frommel, 2003: 16-18 y Frommel, 2009: 77-81.

20 Olivato/Puppi, 2007: 221-226.

${ }^{21}$ El proyecto de Bramante fue modificado primero por Pirro Ligorio y más tarde por Domenico Fontana, que fue quien dividió el inmenso patio al partirlo con la biblioteca (Portoghesi, 1979: 44-48 y Borsi, 1989: 264-272).

${ }^{22}$ El colegio, hoy llamado de los Irlandeses, fue fundado por el arzobispo Alonso de Fonseca. En las obras venía trabajando desde 1521 Juan de Álava, que será quien continúe el edificio después de 1529 siguiendo las nuevas trazas para el patio y la portada que da Siloe (Gómez Moreno y Martínez, 1983: 61, Camón, 1982: 150-156 y Marías, 1989: 426). 


\section{Miradores en plazas españolas}

Si Italia ofreció a Siloe modelos compositivos que supo adaptar con magistral elegancia a la realidad hispana, en España pudo conocer numerosos ejemplos de edificios miradores, pues a mediados del siglo XVI ya había una importante tradición de plazas mayores y edificios dotados con galerías y balcones para que las autoridades presenciaran los eventos que en ellas se desarrollaban. Los edificios miradores que podemos encontrar en Castilla realizados a finales del siglo XV o durante la primera mitad del XVI son muy diversos, pues van desde los balcones corridos de madera o de hierro, a las arcadas superpuestas. En la propia Granada se construyó entre 1518 y 1521 un edificio cuya planta inferior era una Lonja municipal y el segundo un gran salón propiedad de la Capilla Real. El cuerpo inferior se componía de una galería de arcos de medio punto sobre columnas torsas, que pudo estar cerrada con rejas, y el segundo cuerpo constaba de una galería de arcos rebajados abierta a la plaza, la cual estaba delimitada por la Capilla Real y el palacio de la Madraza (sede del cabildo municipal). Esta plaza, aunque pequeña e irregular, era un espacio central de la ciudad que con frecuencia recorrían procesiones religiosas y cortejos cívicos que partían de los citados edificios ${ }^{23}$.

Hay algunos miradores construidos por cabildos municipales en fechas coetáneas o posteriores al de Granada que presentan diseños con más diferencias que similitudes en relación al modelo de Siloe. La sede consistorial de Úbeda contaba con un elegante edificio (1550-1560) con dos galerías mirando a distintas plazas. Una de ellas ha desaparecido; la que permanece tiene un primer cuerpo con tres vanos arqueados que apean en columnas pareadas, mientras que el segundo presenta dos pequeños arcos por cada uno del cuerpo inferior, alternando columnas individuales con dobles. El edificio se cierra a los lados con machones que lucen escudos y hornacinas ${ }^{24}$.

En Sevilla la plaza de San Francisco, como la plaza de Bibarrambla, recordaba un corral de comedias, con sus sencillos edificios adintelados sobre pies derechos de aire mudéjar. En contraste con ellos el Ayuntamiento era una suntuosa obra de cantería a la que Hernán Ruiz II anexó en 1563 una logia de dos cuerpos de alzada con sencillos arcos sobre columnas ${ }^{25}$.

La plaza Mayor de Guadix tenía en uno de los lados menores el balcón de los Corregidores (1606), mirador que constaba de dos cuerpos de alzada, el primero con robustas columnas toscanas soportando arcos escarzanos y el segundo con columnas jónicas y arcos de medio punto, galería esta que fue cerrada colocando ventanas con frontón; el edificio se remataba con balaustrada y tres escudos colocados en los ejes de las columnas. En los extremos, la sucesión modular de arcos se cerraba con torretas rematadas por un bajo chapitel con jarrón. Las analogías compositivas con la casa de los Miradores son evidentes en el remate con los escudos y en el cierre de los módulos de arcos en los extremos, pero se diferencia en que las columnas no están adosadas a pilares ${ }^{26}$.

En el Ayuntamiento de Toledo (1574) Juan de Herrera edificó un primer cuerpo con una composición inspirada en el Coliseo y concibió de la misma manera el piso principal. Si este

${ }^{23}$ La Lonja fue trazada probablemente por Enrique Egas o algún maestro de su entorno. Sirvió como lonja durante pocos años, pues resultaba angosta (León, 1990: 33-40 y 59-66). Joaquín Bárchez y Fernando Marías consideran que su tipología parte del modelo medieval desarrollado en otras ciudades españolas, pero bajo la posible influencia del libro de Fra Luca Pacioli De divina proportione (1509), en el cual se publicaba una reconstrucción de la porta Speciosa del Templo de Jerusalem (Bérchez/Marías, 2010: 203).

${ }^{24}$ No se sabe quien lo trazó, sólo que trabajó el cantero Antón Sánchez y que las obras fueron visitadas por Vandelvira (Moreno, 1993: 208-212). Sobre otros miradores andaluces véase López, 2006: 47-51.

25 Camón, 1982: 329-33, Marías, 1989: 400. Ha sido calificada como "una loggía, de amplio sabor italianizante, que servía al Cabildo de palco público para presidir y presenciar cuantos espectáculos de cualquier índole, se tenían en la plaza" (Banda, 1974: 155-156). Esta logia-mirador fue destruida en una reforma de 1866.

${ }^{26}$ Desconocemos quién trazó el edificio, aunque se sabe que trabajó en la primera etapa de las obras Juan Caderas de Riaño, un cantero cántabro también empleado en la Catedral. Incendiada la plaza durante la Guerra Civil, la fachada del Balcón de Corregidores fue reconstruida en la posguerra en el lado opuesto de la plaza para servir de fachada del Ayuntamiento. La reconstrucción no fue literal, sino que modificó la ubicación de los escudos del ático, amén de otros detalles (Sanguinetti, 1949: 317-324, Asenjo, 2000: 215-217 y Cambil/Arias, 2014: 335-360). 


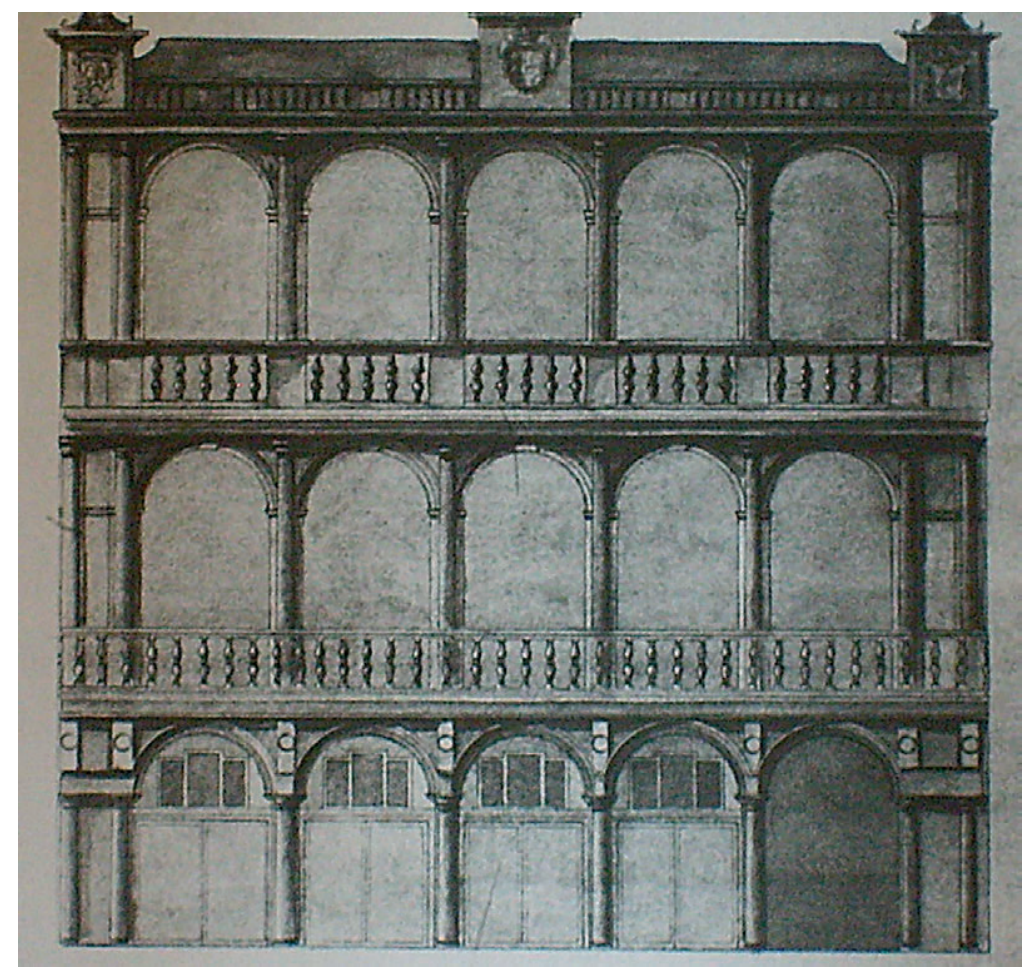

Fig. 5. Casa de los Miradores (hacia 1620, Archivo Histórico Nacional).

hubiera seguido el esquema previsto el parecido con los Miradores de Granada habría sido notable, no en vano algún erudito granadino del siglo XIX atribuía la casa de los Miradores a Herre$\mathrm{ra}^{27}$. Sin embargo, Jorge Manuel Tehotocópuli alteró con poca fortuna el proyecto al sustituir las arquerías del segundo piso por vanos adintelados ${ }^{28}$. En realidad donde encontramos con más frecuencia la combinación de estructura de arcos con piel adintelada y superposición de órdenes es en dos patios de Herrera, el de los Evangelistas del Escorial y el de la Lonja de Sevilla, o en otro de Juan Gómez de Mora, la Universidad de Alcalá de Henares.

\section{Reformas y uso del edificio}

\section{Reformas de los siglos XVII y XVIII}

En un dibujo que podríamos fechar hacia 1620 puede verse que cuatro de los arcos de la galería baja se han cerrado con portones de madera dejando en la parte superior triples vanos para la iluminación del portal o de un altillo ${ }^{29}$. El único arco que no se cierra es el que se corresponde con la puerta de las Cucharas (fig. 5).

27 Giménez-Serrano, 1846: 173.

28 Fernando Marías lo califica de arquitecto incompetente en el campo técnico, con una formación que no llegaba a la de un maestro de obras y empeñado en "salir del clasicismo desde el propio clasicismo" (Marías, 1983: 206-207, tomo II).

${ }^{29}$ En un libro de las fincas de propios del año 1610 se indica que hay una tienda arrendada en los bajos del Mirador de la ciudad y parece deducirse que ésta puede ser suprimida si se decide hacer una escalera. También se alquilaban algunos aposentos altos del edificio (AHMG, leg. 18-175). La imagen la dato hacia 1620 porque en la galería inferior hay unos cierres de madera que no vemos en el dibujo de 1616 (fig. 2) y no está la ampliación del balcón que se hizo en 1624 . 


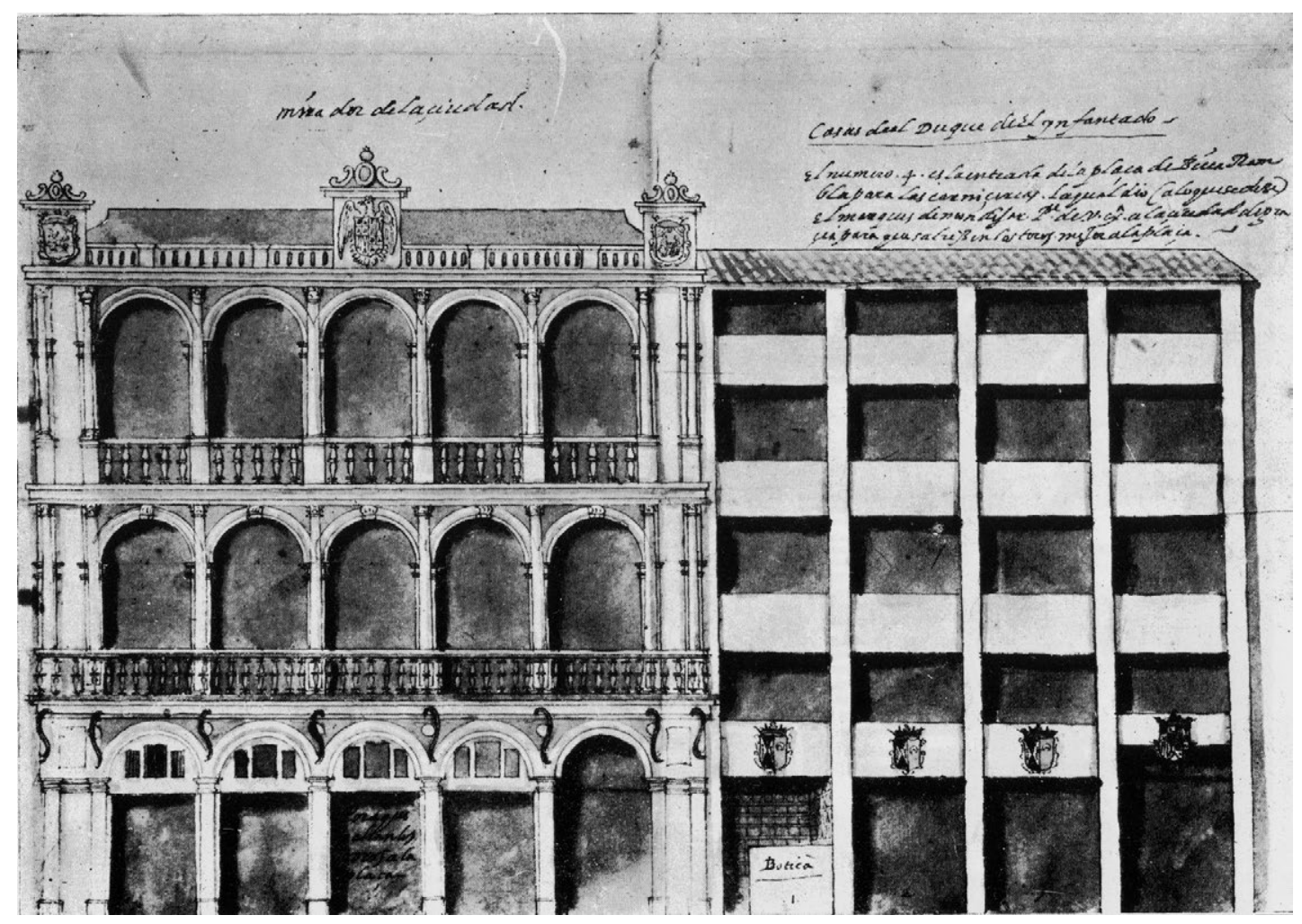

Fig. 6. Casa de los Miradores (después de 1624, Archivo Histórico Nacional).

El edificio acabaría quedándose pequeño con el tiempo y, coincidiendo con la visita de Felipe IV a la ciudad, se decidió ampliarlo. Así, el solar fue ensanchado en 1625 por Francisco de Barea hacia la calle Boteros a costa de derribar la muralla nazarí, lo que dio bastante fondo a un edificio inicialmente estrecho. Ello supuso la construcción de una escalera secundaria para comunicar dependencias que tenían un carácter accesorio, si es que no autónomo, dentro del conjunto arquitectónico ${ }^{30}$. La reforma que sí afectó directamente a la composición de la fachada de los Miradores fue la ampliación del suelo del balcón, realizada en las mismas fechas con la evidente intención de hacer más cómoda la asistencia a los fastos que con motivo de la visita real se celebraron en la plaza; se colocó para ello un balcón corrido de hierro dorado sobre fiadores, de lo que se encargó el maestro cerrajero Juan de Barea ${ }^{31}$ (fig. 6).

En 1739 muchas de las dependencias del edificio dejaban bastante que desear, sobre todo las habitaciones traseras que daban a la calle Boteros, en las que era frecuente el cambio de usos, por lo que se llevaron a cabo importantes obras de reforma que por diversas circunstancias se prolongaron hasta 1743: se habilitaron nuevas dependencias, se subdividieron otras, se colocaron rejas, se repararon techumbres colocando una canal de teja vidriada y se puso una tinaja. En la fachada se reparó un guardapolvos del balcón principal que había sido colocado años atrás y en las dependencias del cabildo municipal hubo cambios en la ornamentación, en particular en la escalera, donde se abrieron dos ventanas para darle luz, lo que obligó a ubicar a mayor altura el

${ }^{30}$ En un portal de las dependencias de la calle Boteros se instaló la Aduana de Paños y Lienzos, que funcionaba de manera autónoma a los Miradores, hasta el punto de que en el primer tercio del siglo XIX la Real Hacienda cuestionaba que sus dependencias fueran de propiedad municipal (AHMG, leg. 63-97, 3649-262 y 3561-77).

31 Se colocó una inscripción aludiendo a que la obra había sido promovida por el corregidor García Bravo de Acuña (López, 1987: 522). 


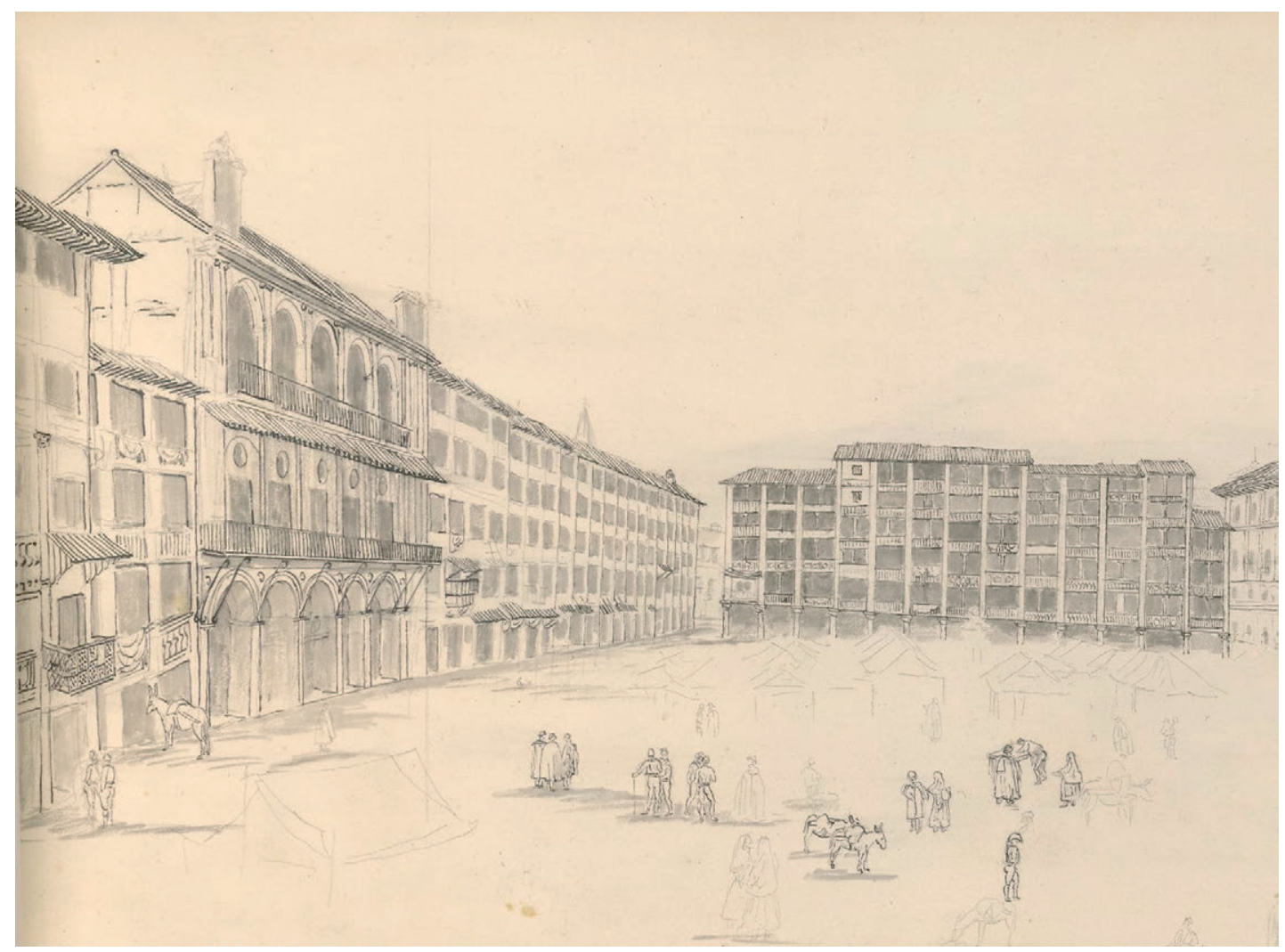

Fig. 7. Plaza Bibarrambla con los Miradores a la izquierda (detalle de un dibujo de William Gell, 1809, British Museum).

águila imperial y el escudo de armas que la decoraban; se dudó entonces si cubrir la escalera con un techo de madera o con una bóveda de yeso. Realizó las obras el maestro mayor de la ciudad Jerónimo de Palma, pero ante los problemas que surgían y una ausencia de la ciudad del artífice, se pidió también informe a Francisco Pérez Orozco, maestro mayor de obras de la Alhambra ${ }^{32}$. Es probable también que en el curso de estas reformas se suprimiera el escudo central del ático del edificio, pues ya no lo vemos en el grabado realizado en 1760 con motivo de la proclamación de Carlos III. En las décadas siguientes se sustituyeron las barandillas de balaustres de los pisos principal y superior por sencillas rejas de hierro ${ }^{33}$ (fig. 7).

\section{Celebraciones en el Antiguo Régimen}

Durante las celebraciones del Corpus, proclamaciones de reyes o corridas de toros la depurada geometría del edificio era transfigurada por colgaduras, cuadros, luminarias y otros ornamentos efímeros que lo adaptaban a los objetivos ideológicos y la estética de cada época.

\footnotetext{
32 Los primeros informes sobre el estado del edificio datan de 1739, pero el grueso de las obras se desarrolló en 1740, aunque todavía en 1743 se trabajaba en la reparación del guardapolvos del balcón principal (AHMG, leg. 63-97 y Olmedo, 2002, p. 95).

${ }^{33}$ Las balaustradas pueden verse en las imágenes de 1620-1650 (la primera sin tornapuntas en el piso principal y la segunda con ellas), y todavía están en el grabado de 1760, mientras que las rejas sencillas las vemos ya en los dibujos de William Guell de 1809.
} 


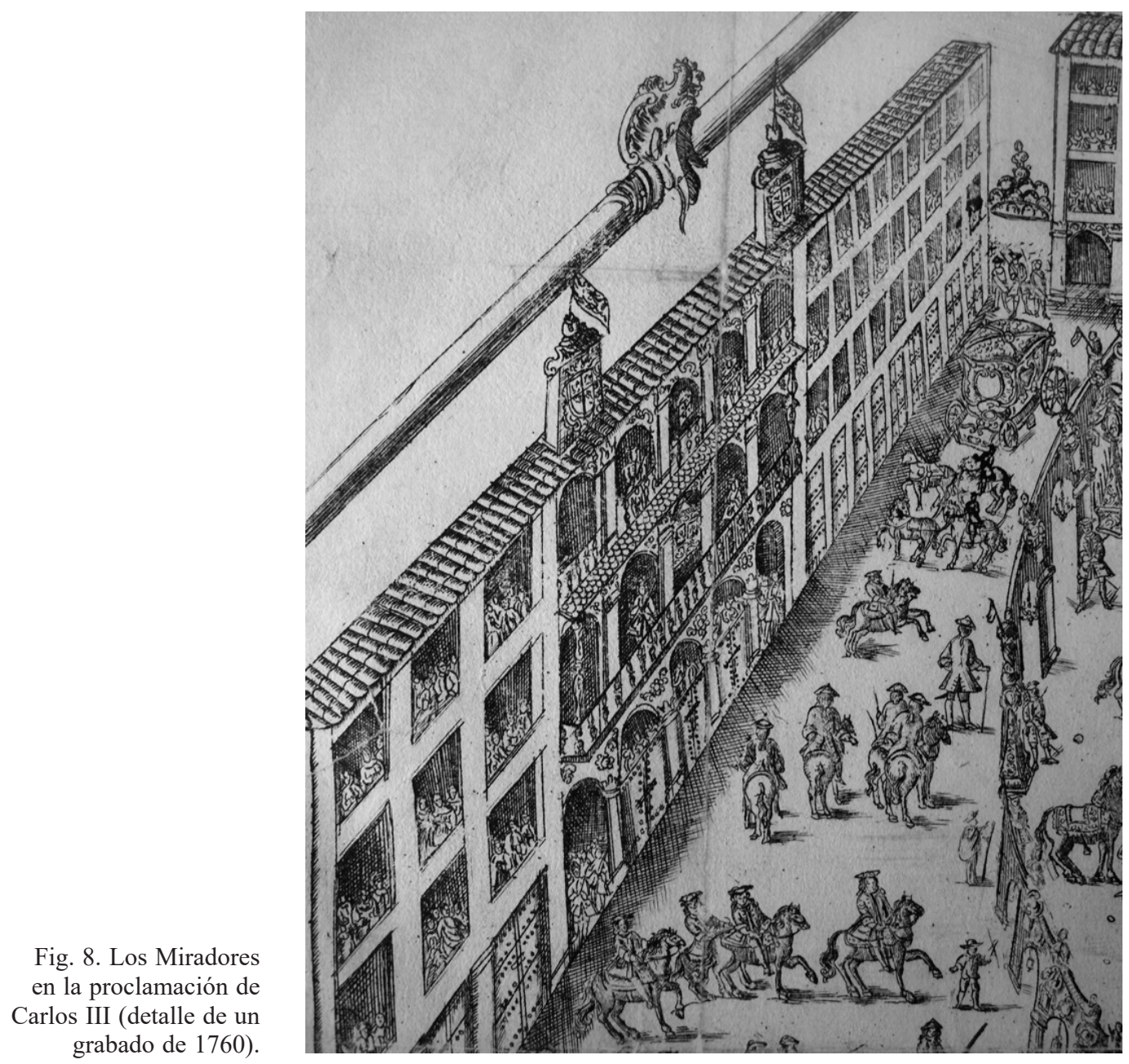

La plaza de Bibarrambla fue el escenario principal de la fiesta del Corpus, que en Granada tuvo siempre un esplendor que sirvió de modelo a otras ciudades españolas. Contamos con numerosas y en ocasiones precisas descripciones sobre las fiestas durante el barroco. Las celebraciones eran muy costosas, pues exigían levantar un gran monumento efímero, ornar toda la plaza colocando galerías de arcos para configurar calles en los lados, dar sombra con toldos, decorar con láminas, espejos, flores, plantas y altares, embellecer los balcones con colgaduras, realizar aparatosas iluminaciones nocturnas con miles de luces o encender castillos de fuegos artificiales. La casa de los Miradores quedaba parcialmente oculta por las galerías que se colocaban en la plaza para convertirla en un claustro, y en sus arcos ocultos a las miradas tocaba un grupo de músicos que causaba maravilla entre el público, pues este no veía de donde procedían los acordes. También en los Miradores se ubicaba el piquete de soldados que custodiaba la plaza para evitar el robo de sus adornos.

Durante los juegos de cañas y corridas de toros, que fueron muy frecuentes en el siglo XVII y primera mitad del XVIII, los munícipes se instalaban en los Miradores. En estas ocasiones se construían en la plaza graderíos de madera rodeándola a una altura que no superaba el primer cuerpo de los edificios ${ }^{34}$. Las corridas de toros dejaron de celebrarse a partir de 1768 , cuando la

${ }^{34}$ Así lo pone de manifiesto un informe para armar las andamiadas en 1720, informe del cual también se desprende que la casa de los Miradores estaba en buen estado, al contrario que otros muchos edificios de la plaza (AHMG, leg. 35-31). 
Real Maestranza de Caballería, principal organizadora de este tipo de eventos, construyó una plaza de toros permanente en el Campo del Triunfo.

En la plaza de Bibarrambla también se celebraban las fiestas y conmemoraciones ligadas a la monarquía. En la proclamación de Fernando VI, por ejemplo, la plaza fue decorada en su centro con un monumento de arquitectura lignaria con abundante heráldica, un jardín con fuentes y cipreses, arcadas vegetales adornadas con arañas y espejos, etc. En este teatro a cielo abierto desfilaron durante tres jornadas las autoridades, se celebró un baile de máscaras y se quemó un castillo de fuegos artificiales. En la casa de los Miradores se colgó un retrato del rey bajo dosel, acompañado por un cuerpo de guardia, y desde una de sus galerías tocó una orquesta 35 .

Para la proclamación de Carlos III en enero de 1760 la plaza se adornó suntuosamente y un grabado y un largo poema inmortalizaron su transfiguración. En la casa de los Miradores se pusieron en un dosel dorado los retratos de Carlos III y María Amalia cubiertos por una cortina roja que se correría en el momento de la proclamación, mientras el resto del edificio se adornaba con fábulas, símbolos y el escudo con las armas reales ${ }^{36}$ (fig. 8). En el último tercio del siglo se cerró la galería del piso principal dejando vanos adintelados con un óculo ornamental sobre ellos, solución que aunque modificaba el proyecto de Siloe era de indudable elegancia; esta reforma demuestra que la función de mirador perdía peso en el uso del edificio frente a la necesidad de oficinas complementarias del cabildo ${ }^{37}$.

\section{Reformas del siglo XIX}

En 1807 y 1808 el edificio fue objeto de algunos reparos menores ${ }^{38}$, gracias a lo cual era un inmueble en buenas condiciones de uso al empezar la Guerra de la Independencia. Por ello las autoridades militares lo reclamaron para instalar una escuela militar de preferencia ${ }^{39}$. Este uso no sentó bien al edificio, pues año y medio después las nuevas autoridades francesas debieron realizar reparos en las dependencias que había ocupado el ejército ${ }^{40}$, para poder destinarlo a un uso político ${ }^{41}$.

El 19 de marzo de 1814 los munícipes decidieron celebrar el aniversario de la Constitución de Cádiz y lo hicieron con una parafernalia cuya estética era deudora de las celebraciones dieciochescas que anunciaban una boda real o el nacimiento de un infante, aunque el contenido ideológico fuera bien distinto. Calles y plazas fueron engalanadas y en la casa de los Miradores su "galería principal fue adornada con pabellones, estatuas, gallardates, trofeos y emblemas de un efecto admirable, descendiendo de su Architrave un juego vistosísimo de fanales y arañas, a que correspondía la galería segunda con grupos de luces, quadros de rebervero y figuras iluminadas del mejor gusto". El retrato del rey se ubicó en "el pabellon principal del centro con la guardia correspondiente”. Esta decoración se completaba con tres lienzos alegóricos colgados de los balcones, uno con textos alusivos a las Cortes, otro con Hércules victo-

\footnotetext{
${ }^{35}$ Una minuciosa descripción de esta fiesta en Cuesta, 1995: 224-227, y un informe sobre el estado y arreglo de la plaza en AHMG, leg. 907-15.

36 Porcel y Salablanca, 1760: 52-54.

37 La galería del piso principal está despejada en el grabado de 1760 y cerrada en el dibujo de William Gell de 1809; las corridas de toros dejaron de celebrarse en la plaza en 1768, marcando el declive de ésta como teatro a cielo abierto.

${ }^{38}$ En una de las obras llevadas a cabo en el edificio intervino el maestro carpintero Luis Quiros (AHMG, leg. 128-32 y Junta de Propios y Arbitrios, 18 enero 1808).

${ }^{39}$ El edificio había sido objeto de algunos reparos ese mismo año (AHMG, Actas Capitulares, 6 diciembre 1808).

${ }^{40}$ Hubo además otros reparos rutinarios, como el arreglo de los tejados, la limpieza de la tinaja y la mejora de la casa del portero (AHMG, Actas Capitulares, 30 junio 1810, y Junta de Propios y Arbitrios, 27 julio, 3 agosto, 14 septiembre y 16 noviembre 1810).

41 AHMG, Actas Capitulares, libro 153, 1 mayo 1815.
} 
Fig. 9. Casa de los Miradores en 1834 (detalle de una acuarela de Luis Muriel, colección particular).

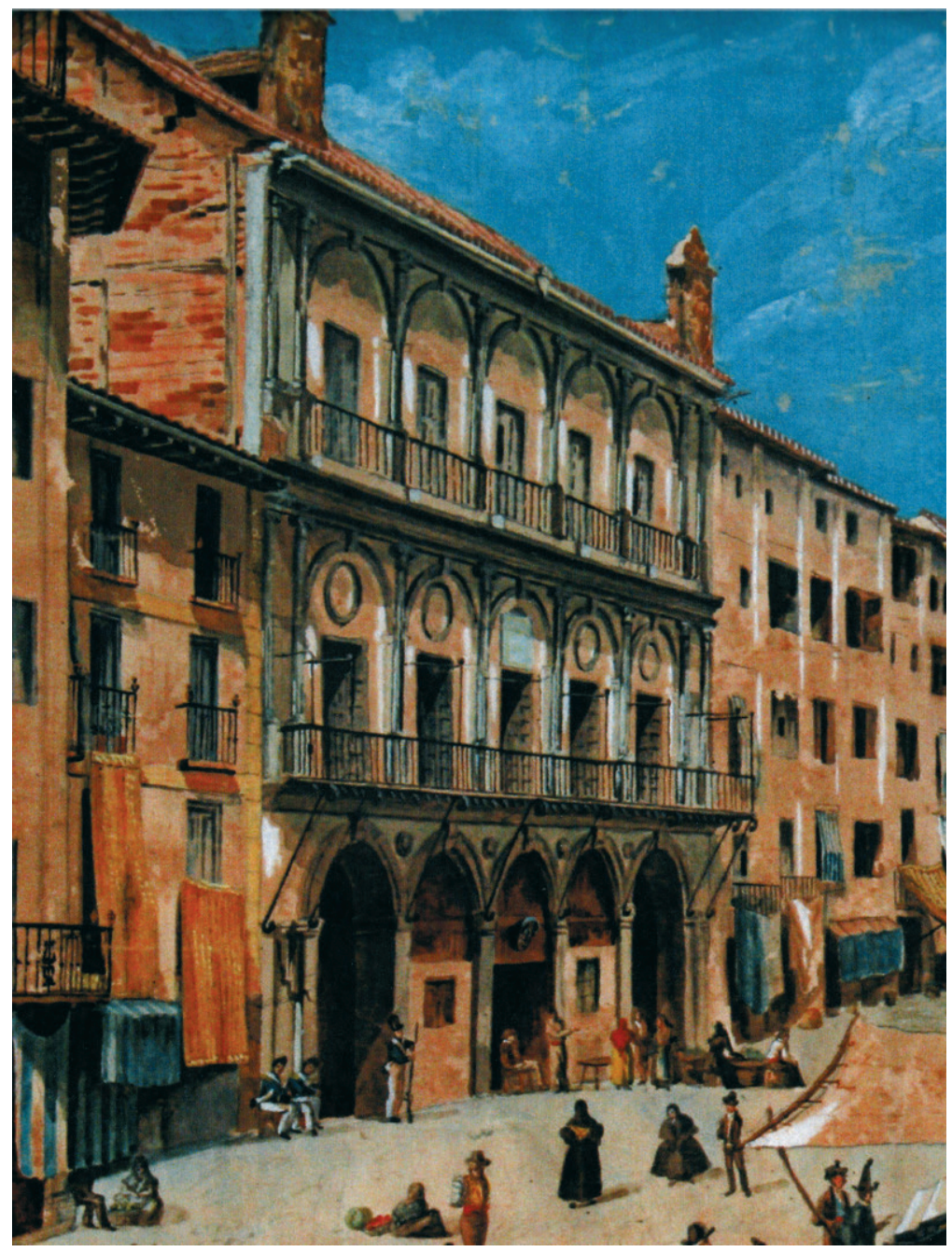

rioso y el tercero mostrando la caída del "tirano Napoleón" acompañado de José Bonaparte y sus mariscales ${ }^{42}$.

Semanas después la situación política dio un giro radical y la plaza de Bibarrambla fue objeto de un evento político bien distinto, la proclamación de Fernando VII. Una turba destruyó la inscripción que había rebautizado la plaza de Bibarrambla como de la Constitución, y colocó en los Miradores el retrato de Fernando VII bajo palio ${ }^{43}$.

Dos años después el Ayuntamiento acordó que todos los edificios de la plaza de Bibarrambla, incluida la casa de los Miradores, debían pintarse de color blanco, con las puertas y ventanas en verde y trazar una cenefa negra aplomada desde el suelo a la altura conveniente, con lo que "se evitará la deformidad que hoy presenta la plaza" ${ }^{4}$. Este despectivo comentario demuestra que en

${ }^{42}$ La cita textual procede de un folleto conservado en la Biblioteca Nacional: Función nacional..., 1814. Véase también AHMG, leg. 908-19.

43 Relato de los acontecimientos conservado en la Biblioteca de la Universidad de Granada e incluido como apéndice en Díaz, 1982: 185-189.

${ }^{44}$ AHMG, Actas del Cabildo, libro 154, 6 agosto 1816. 
el municipio se había impuesto el deseo de dotar de regularidad a una plaza cuya estética pintoresca no apreciaba y que estaba, todo hay que decirlo, muy deteriorada.

En 1832 se dotó a los Miradores de un pilar de agua, no queda claro si sustituyendo o complementando a la tinaja de la que ya disponía. El pilar tuvo un funcionamiento que dejaba mucho que desear, pues su excesivo uso y escasa limpieza lo convirtieron en un foco de insalubridad además de ocasionar frecuentes filtraciones ${ }^{45}$. Más trascendencia para la fisonomía del edificio tuvo el cierre de la galería superior, según muestra un dibujo de Luis Muriel, pues se dejaron sólo estrechos vanos adintelados para acceder al balcón de hierro, de manera análoga a lo que se había hecho antes con el piso principal. También se suprimió el guardapolvos que protegía el balcón del piso principal (fig. 9).

El día de la Constitución de 1837 se celebró en la plaza de Bibarrambla con extraordinario fasto. Los vecinos adornaron sus balcones con colgaduras y las autoridades hicieron lo propio con los edificios institucionales, entre los cuales estaba el de Miradores, donde se formó "una fachada de transparente [...] compuesta de un cuerpo ático de arquitectura griega, dividido en cinco cuadros con las alegorías y versos" alusivos a la Constitución ${ }^{46}$. Aquel mismo año el Ayuntamiento liberal comenzó una remodelación de la plaza que, a lo largo de varias fases, la redujo en dimensiones para formar un perfecto rectángulo, lo que implicó la reconstrucción de todos sus edificios mudéjares para levantar inmuebles con fachadas simétricas y sobria ornamentación academicista. Esta remodelación de la plaza se prolongaría durante varias décadas y fue convirtiendo a la casa de los Miradores en un edificio descontextualizado y en un estorbo a los planes de alineaciones ${ }^{47}$.

Hacia 1840 la casa de los Miradores fue decorada "con pinturas de estatuas y con renovación de las armas que coronaban este edificio" 48 . Estas pinturas se pueden observar en algunas fotografías antiguas y consistían en figuras alegóricas, unas de cuerpo completo ubicadas entre las medias columnas de los machones, otras decorando los tondos de los vanos del piso principal y otras figurando tondos en el cuerpo superior (fig. 10).

El edificio cada vez se usaba menos como mirador dado que la plaza de Bibarrambla no era ya ese gran teatro a cielo abierto que había sido en el pasado, con la excepción de las fiestas del Corpus. Su función como sede complementaria del Ayuntamiento también perdió peso, pues en 1851 los munícipes se trasladaron al exclaustrado convento del Carmen, a la par que conservaban su antigua sede de la Madraza. Por ello algunas partes de los Miradores, en especial los portales y dependencias de la primera planta, se irán destinando a otros fines (juzgados de primera instancia, calabozo, Sociedad Mercantil y Archivo de Protocolos Notariales ${ }^{49}$ ). Incluso la sala principal del edificio se alquilará en ocasiones para celebrar diversos tipos de funciones ${ }^{50}$, mientras que unos cuartos bajos se ceden a un comerciante para destinar el dinero del arrendamiento a "atender a la reparación y conservación de todo el edificio" 51 . No en vano en 1857 un reconocimiento del arquitecto José Contreras señalaba la necesidad de importantes reparos ${ }^{52}$. Aunque se acometieron algunas obras, el deterioro del edificio continuó acentuándose. En 1865 se hablaba

45 AHMG, leg. 3561-82.

46 Descripción de las diversiones..., 1837: 10-11.

47 Para la transformación de la plaza de Bibarrambla véase Acale, 2005: 286-322.

48 La mención más antigua que tenemos de esas pinturas está en el texto del Diccionario geográfico de Madoz, que fue redactado por Lafuente Alcántara y está fechado en mayo de 1847 (Madoz, 1852: 130).

${ }^{49}$ El archivo contaba, además de los protocolos notariales, con otra documentación que incluía algunos manuscritos árabes, sumando un total de 10.000 volúmenes. El gran peso de los legajos hizo que unos peritos revisaran la solidez del edificio y se estimó que "se encontraba en las mejores condiciones" (La Lealtad, 31/01/1880).

${ }^{50}$ Por ejemplo, en 1851 solicitó su alquiler el director de la compañía de Teatro de Autómatas, Juan José Picazo, para representar "Dramas de Espectáculo y Comedias de Magia, adornadas con magníficas decoraciones" (AHMG, leg. 908-35).

51 AHMG, leg. 3577-5.

52 Era necesario reparar un muro quebrado en una de las medianerías, consolidar una parte del techo del salón que amenazaba ruina, arreglar los importantes desperfectos en las solerías de ese salón y en la escalera principal, y renovar unos tejados que sufrían recalos. Informe fechado el 7 mayo 1857, AHMG, leg. 43-76. 
Fig. 10. Corpus de 1867, a la derecha, tras una galería efímera, pueden verse los Miradores (fotografía antigua).

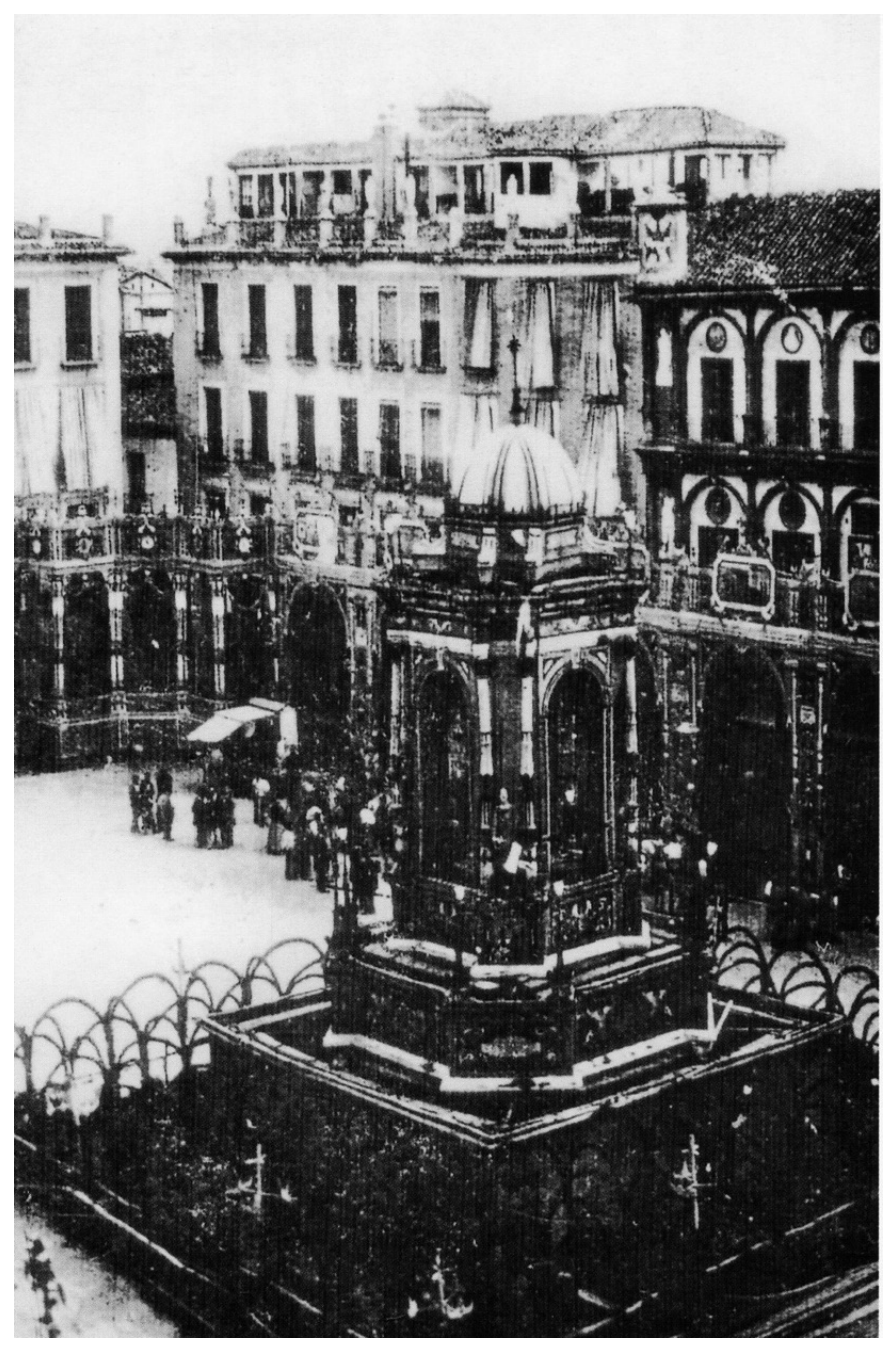

de estado de ruina en las dependencias que ocupan los juzgados ${ }^{53}$. Tras esta denuncia se llevaron a cabo obras para rehabilitar estas dependencias y el calabozo, ya en desuso, que se quería utilizar como oficina del comisario de vigilancia, además de eliminar goteras que caían sobre las escaleras ${ }^{54}$.

En 1876 los juzgados elevaron una reclamación contra el Ayuntamiento en la que lamentaban que el espacio disponible en el edificio fuera tan reducido que apenas podían contar con "tres mezquinos despachos para los jueces, una sala o ante despacho común a los tres juzgados y una mezquina habitación para el alguacil conserje, sin que haya una sala conveniente para vistas y actos públicos, otra de escribanos y un almacén o depósito de efectos y cuerpos de delito". En definitiva, los jueces pidieron el adecentamiento del lugar y más dependencias del edificio para evitar "el desprestigio de la justicia". Estas quejas motivaron el arreglo de los tejados amén de otras reformas menores que se dieron por concluidas en agosto de $1877^{55}$.

\footnotetext{
53 AHMG, leg. 1904-47.

54 Noticia fechada el 16 enero 1865 (AHMG, leg. 1904).

55 AHMG, leg. 37-50.
} 


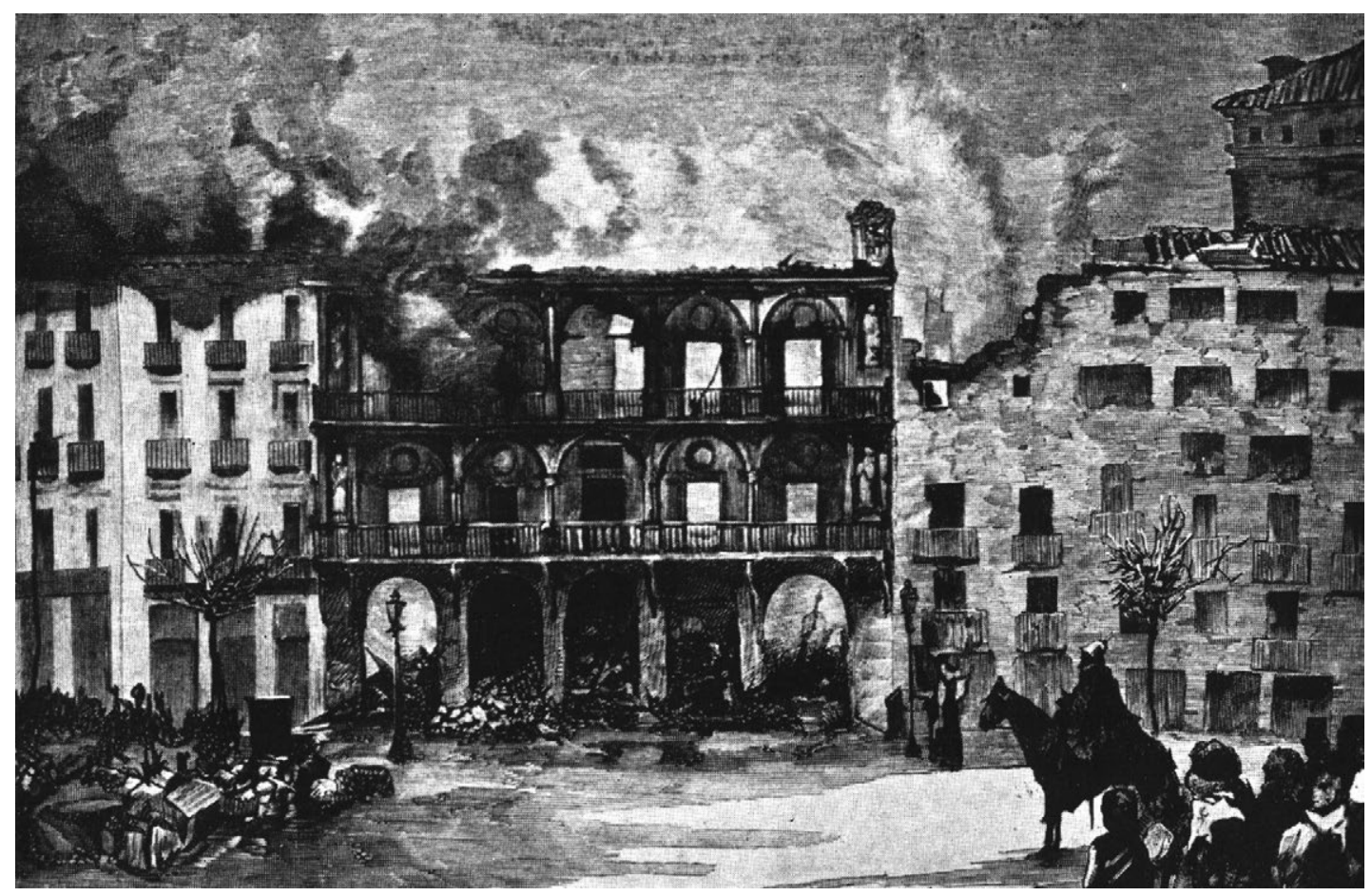

Fig. 11. Los Miradores en ruinas tras el incendio de 1879 (dibujo de Valentín Barrecheguren).

\section{Destrucción de la casa de los Miradores}

Salvo los habituales reparos necesarios para la conservación de un edifico, la casa de los Miradores era una construcción sólida que podría haber llegado perfectamente a nuestros días si no llega a ser por el grave incendio que sufrió el 31 de diciembre de 1879. El siniestro se inició en el establecimiento comercial de ropas que había en los bajos del edificio, un local que paradójicamente el Ayuntamiento mantenía arrendado para aplicar su producto a la conservación del edificio. Las llamas se propagaron con inusitada violencia y rapidez, falleciendo un empleado y resultando heridas otras tres personas, y dejaron reducido a escombros el interior de los Miradores, perdiéndose buena parte del Archivo de Protocolos Notariales ${ }^{56}$. La fachada de piedra, sin embargo, se mantuvo en pie demostrando su buena estereotomía y podría haberse conservado sin grandes problemas si se hubiera optado por reconstruir el interior del edificio. La noticia del incendio fue recogida no sólo por la prensa local, sino también por publicaciones como La ilustración española y americana, que la acompañó de dos grabados sobre dibujos del pintor granadino Valentín Barrecheguren. El periódico lamentó la destrucción de un edificio que todavía atribuía erróneamente al arquitecto Juan de Herrera: "Cuantos admiradores cuenta el tesoro de bellezas artísticas que en monumentos arquitectónicos encierra nuestra patria deplorarán, como nosotros, la destrucción de la Casa de los Miradores"57 (fig. 11).

La opción de conservar la fachada no fue contemplada en absoluto por el municipio, dado el elevado costo que suponía para sus exhaustas arcas recuperar un edificio que hacía muchos años que había perdido su función de mirador y cuyos salones ya no necesitaba. El Ayuntamiento

56 Escribió Valladar: "Hoy, del archivo sólo restan algunos legajos medio destruidos por el fuego y del histórico edificio un montón de piedras calcinadas" (La Lealtad, 31/01/1880).

57 La ilustración española y americana, 15/01/1880. 
prefirió enajenar el solar para obtener recursos económicos y culminar la regularización de la plaza de Bibarrambla ${ }^{58}$. Los restos de la casa de los Miradores fueron demolidos y sólo una media columna corintia de la galería superior se trasladó al Museo Arqueológico Provincial.

Una porción del solar de los Miradores sirvió para abrir la calle de las Cucharas, reforma urbana que supuso la desaparición de la puerta homónima ${ }^{59}$. La mayor parte del solar fue ocupada por un edificio diseñado por el arquitecto Cecilio Díaz de Losada ${ }^{60}$, el cual se preveía ricamente ornamentado y evocaba la desaparecida casa de los Miradores con la colocación de una arquería cerrada en el cuerpo bajo. Sin embargo, este proyecto se acabó simplificando por cuestiones presupuestarias dando lugar a un inmueble ecléctico de escaso interés, aunque la prensa de la época lo calificaba de "magnífico edificio" que "hermosea" la plaza, impresión compartida por los munícipes ${ }^{61}$.

\section{Conclusiones}

Para el erudito Manuel Gómez-Moreno González este "notable edificio por desgracia perdido" era "bellísimo" y "lo más clásico que salió de manos del gran maestro" 62 . Su hijo Manuel Gómez-Moreno Martínez señalaba que el edificio "resultó modelo ejemplar entre nosotros", o sea, que era peculiar para los españoles de la época, aunque no para los italianos. No deja de ser curioso que ese autor califique como "infantilismo en su vejez aquel alarde purista con que exaltó su proyecto para los Miradores" ${ }^{63}$. Lejos de esta peculiar valoración Fernando Marías estimó su composición, realizada sobre "el sintagma albertiano", "como un compendio del saber definitivo de Diego de Siloe [...] y como un manifiesto de sus creencias" 64 .

En efecto, la casa de los Miradores constituía la obra de madurez de un arquitecto que había ido abandonando el gusto por la ornamentación presente en sus obras desde la Escalera Dorada de la Catedral de Burgos a la puerta del Perdón de la Catedral de Granada. Tanto en los Miradores como en la inacabada iglesia parroquial de Iznalloz encontramos un lenguaje más sobrio y geométrico que tendrá continuidad en Castilla con El Escorial, pero no en Andalucía, donde la profusión ornamental de la fachada de Francisco del Castillo el Mozo para la Chancillería de Granada supone la conexión con una Italia muy diferente a la que Siloe conoció.

El concepto de edificio mirador para las autoridades contaba con numerosos precedentes en España cuando Siloe recibió el encargo, pero él prefirió tomar como modelo la imponente Logia de la Bendición del Vaticano, una obra trazada por Francisco del Borgo, discípulo de Alberti y basada en el Coliseo. Se inspiró en ella con libertad, como prueban no sólo los escudos de remate o los machones laterales, sino también la galería de pequeños arcos que debía coronarla y no llegó a ejecutarse. Por desgracia, tanto la Logia de la Bendición como la casa de los Miradores son hoy edificios desaparecidos.

\section{BIBLIOGRAFÍA}

Acale Sánchez, Fernando (2005): Plazas y paseos de Granada. De la remodelación cristiana de los espacios musulmanes a los proyectos de jardines en el ochocientos. Granada: Universidad de Granada y Atrio.

Asenjo Sedano, Carlos (2000): Arquitectura religiosa y civil de la ciudad de Guadix. Siglo XVI. Granada: Universidad.

58 AHMG, leg. 1983-26.

59 Seco, 1884: 60.

${ }^{60}$ Los informes municipales sobre el siniestro, la tasación del solar y su venta, así como la aprobación del diseño del arquitecto Cecilio Díaz de Losada para un nuevo edificio en AHMG, leg. 26-21, 26-134 y 1983-26.

${ }^{61}$ La Tribuna, 13/07/1881.

62 Gómez-Moreno González, 1892: 246.

63 Gómez-Moreno Martínez, 1963: 49 y 67.

${ }^{64}$ Marías, 1989: 399. 
Banda y Vargas, Antonio de la (1974): El arquitecto andaluz Hernán Ruiz II. Sevilla: Universidad de Sevilla.

Bérchez, Joaquín/Marías, Fernando (2010): "Las lonjas de mercado en España: de Barcelona a Sevilla”. En: Ottenheym, Konrad/Chatenet, Monique/De Jonge, Krista (eds.): Public Buildings in Early Modern Europe. Turnhout: Brepols, pp. 201-220. En: https://doi.org/10.1484/m.archmod-eb.4.00177.

Borsi, Franco (1989): Bramante. Milano: Electa.

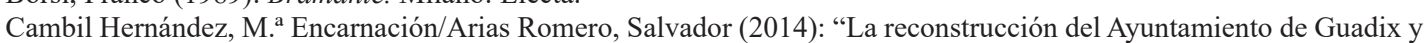
del Balcón de Corregidores tras la Guerra Civil". En: Revista del Centro de Estudios Históricos de Granada y su Reino, 26, Granada, pp. 335-360.

Camón Aznar, José (1982): La arquitectura y la orfebrería españolas del siglo XVI. Madrid: Espasa-Calpe.

Cervera Vera, Luis (1990): Plazas mayores de España. Madrid: Espasa Calpe, vol. 1.

Cuesta García de Leonardo, María José (1995): Fiesta y arquitectura efimera en la Granada del siglo XVIII. Granada: Universidad.

Descripción de las diversiones y recreos públicos con que la ciudad de Granada solemnizó la promulgación... de la Constitución... (1837). Granada: Imprenta de la viuda de Moreno e Hijos.

Díaz Lobón, Eduardo (1982): Granada durante la crisis del Antiguo Régimen (1814-1820). Granada: Diputación.

Frommel, Christoph Luitpold (2003): Architettura alla corte papale nel rinascimento. Milano: Electa.

Frommel, Christoph Luitpold (2009): Architettura del Rinascimento italiano. Milano: Skira.

Función nacional celebrada por el ayuntamiento Constitucional de Granada en el día 19 de marzo... de 1814, aniversario de la publicación de la Constitución política de la Monarquía española (1814). Granada: Oficina de D. Nicolás Moreno.

Gila Medina, Lázaro (2000): Maestros de cantería y albañilería en la Granada moderna, según los escribanos de la ciudad. Granada: Colegio Notarial.

Giménez-Serrano, José (1846): Manual del artista y del viajero en Granada. Granada: Editor J. A. Lincres.

Gómez-Moreno Calera, José Manuel (1989): La arquitectura religiosa granadina en la crisis del renacimiento (1560/1650). Granada: Universidad de Granada y Diputación de Granada.

Gómez-Moreno González, Manuel (1892): Guía de Granada. Granada: Imprenta de Indalecio Ventura.

Gómez-Moreno Martínez, Manuel (1963): Diego Siloe. Homenaje en el IV centenario de su muerte. Granada: Universidad de Granada.

Gómez-Moreno Martínez, Manuel (1983): Las águilas del Renacimiento español: Bartolomé Ordóñez, Diego Silóe, Pedro Machuca, Alonso Berruguete, 1517-1558. Madrid: Xarait.

León Coloma, Miguel Ángel (1990): La Lonja de Granada. Granada: Cámara de Comercio.

López Guzmán, Rafael (1987): Tradición y clasicismo en la Granada del XVI. Arquitectura civil y urbanismo. Granada: Diputación.

López Guzmán, Rafael (2006): "Miradores y logias municipales”. En: PH, 57, Sevilla, pp. 47-51.

Luque Moreno, Jesús (2013): Granada en el siglo XVI. Testimonios de la época. Granada: Universidad de Granada.

Madoz, Pascual (1852): Diccionario geográfico-estadístico-histórico de España y sus posesiones de ultramar. GRANA$D A$. Madrid: Est. Literario-tipográfico de P. Madoz y L. Sagasti.

Marías, Fernando (1983): La arquitectura del Renacimiento en Toledo, 1541-1631. Toledo: Publicaciones del Instituto Provincial de Investigaciones y Estudios Toledanos, 2 vols.

Marías, Fernando (1989): El largo siglo XVI: los usos artísticos del Renacimiento español. Madrid: Taurus.

Moreno Mendoza, Arsenio (1993): Ubeda renacentista. Madrid: Electa España.

Olivato, Loredana/Puppi, Lionello (2007): Mauro Codussi. Milano: Electa.

Olmedo Sánchez, Yolanda (2002): Arquitectura y urbanismo en la Granada del barroco tardio (1667-1750). Córdoba: Universidad de Córdoba.

Porcel y Salablanca, Joseph Antonio (1760): Gozo, y corona de Granada. En la proclamación solemne del rey nuestro señor don Carlos Tercero. Granada: Imprenta Real.

Portoghesi, Paolo (1979): Architettura del Rinascimento a Roma. Milano: Electa.

Sanguinetti, Santiago (1949): "El nuevo Ayuntamiento de Guadix y el Balcón de Corregidores". En: Reconstrucción, 96, Madrid, pp. 317-324.

Seco de Lucena, Luis (1884): La ciudad de Granada. Descripción y Guía. Granada: Imp. El Defensor.

Fecha de recepción: 26-II-2015

Fecha de aceptación: 18-IV-2015 